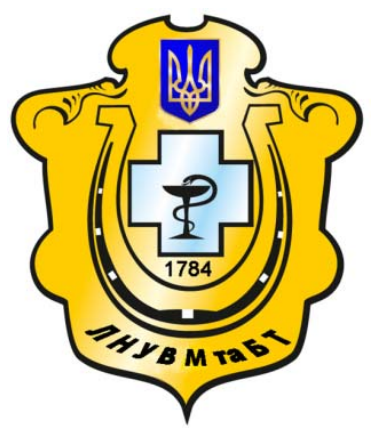

Науковий вісник Львівського національного університету ветеринарної медицини та біотехнологій імені С.3. Гжицького

Scientific Messenger of Lviv National University of Veterinary Medicine and Biotechnologies named after S.Z. Gzhytskyj

doi:10.15421/nvlvet7042

ISSN 2413-5550 print

ISSN 2518-1327 online

$\underline{\text { http://nvlvet.com.ua/ }}$

УДК 577.12:619:616.61

\title{
Дістотерапія дрібних тварин із хронічною нирковою недостатністю
}

\author{
Є.С. Лугова, В.О. Прис-Каденко, А.О. Куліченко, Л.Г. Калачнюк \\ lugovaya.yeseniya@gmail.com; lilkalachnyuk@gmail.com \\ Національний університет біоресурсів і природокористування Украӥни, \\ вул. Героїв Оборони, 15, м. Київ, 03041, Украӥна
}

\begin{abstract}
Дана робота присвячена вивченню метаболічних змін у котів і собак з хронічною нирковою недостатністю (ХНН), використовуючи дієтотерапію при їх лікуванні. Одними із основних показників прогресування ХНН у дрібних тварин є креатинінемія, артеріальна гіпертензія та протеїнурія. Діагностування їх у дрібних тварин із ХНН є важливим етапом для встановлення стадійності та підстадійності захворювання згідно InternationalRenalInterestSociety. Для того, щоб призначити відповідне лікування, його моніторинг та прогнозувати перебіг захворювання діагностують стадійність ХНН, визначаючи кониентрачію креатиніну в сироватиі крові. Поряд з цим є важливим визначення підстадійності ХНН залежно від показників протеїнурії (з'ясуванні причин ї̈ виникнення) та артеріального тиску, який вказуе на ступінь ураження органівмішеней. Звідси, основні зміни у метаболізмі організму дрібних тварин із хронічною нирковою недостатністю торкаються, в основному, обмінних процесів білка та водно-мінерального обміну. Було визначено, шуо утримування котів $і$ собак протягом лікування на дієті RoyalCanin «Renal» (заснованій на низькій концентрації білка, необхідному вмісті електролітів, вітамінів і ліпідів) зменшує в 4 рази тривалість часу виникнення стійкої ремісії у тварин.

Ключові слова: хронічна ниркова недостатність, метаболізм, дієтичне харчування, коти, собаки.
\end{abstract}

\section{Диетотерапия мелких животных с хронической почечной недостаточностью}

\author{
Є.С. Луговая, В.О. Прыс-Каденко, А.О. Куличенко, Л.Г. Калачнюк \\ lugovaya.yeseniya@gmail.com; lilkalachnyuk@gmail.com \\ Национальный університет биоресурсов и природопользования Украины, \\ ул. Героев Обороны, 15, г. Киев, 03041, Украина
}

\begin{abstract}
Данная работа посвячена изучению метаболически изменений у кошек и собак с хронической почечной недостаточностью (ХПН), используя диетотерапию при их лечении. Одними из основних показателей прогрессирования ХПН у мелких животных является креатининемия, артериальная гипертензия и протеинурия. Диагностирование их у мелких животных с ХПН является важным этапом для установления стадийности и подстадийности заболевания согласно International Renal Interest Society. Для того, чтобы назначить соответствующее лечение, его мониторинг и прогнозировать течение заболевания диагностируют стадийность ХПН, определяя концентрацию креатинина в сыворотке крови. Наряду с этим важным является определение подстадийности ХПН в зависимости от показателей протеинурии (выяснении причин еевозникновения) и артериального давления, указывающего на степень поражения органов-мишеней. Отсюда, основные изменения в метаболизме организма мелких животных с хронической почечной недостаточностью касаются, в основном, обменных прочессов белка и водно-минерального обмена. Было определено, что содержание кочек и собак вовремя лечения на диете Royal Canin «Renal» (основанной на низкой концентрации белка, необходимом содержании электролитов, витаминов и липидов) уменьшает в 4 раза продолжительность времени возникновения устойчивой ремиссии у животных.
\end{abstract}

Ключевые слова: хроническая почечная недостаточность, метаболизм, диетическое питание, кошки, собаки.

Citation:

Luhova, Ye.S., Prys-Kadenko, V.O., Kulichenko, A.O., Kalachniuk, L. (2016). Diet-therapy of small animals with chronic renal failure. Scientific Messenger LNUVMBT named after S.Z. Gzhytskyj, 18, 3(70), 178-180. 


\title{
Diet-therapy of small animals with chronic renal failure
}

\author{
Ye.S. Luhova, V.O. Prys-Kadenko, A.O. Kulichenko, L. Kalachniuk \\ lugovaya.yeseniya@gmail.com; lilkalachnyuk@gmail.com \\ National Universityof Life and Environmental Sciences of Ukraine, \\ Heroiv Oborony Str., 15, Kyiv, 03041, Ukraine
}

This work is devoted to the study of metabolic changes in dogs and cats with chronic renal failure (CRF) using diet-therapy during their treatment. One of the main indicators of the progression of chronic renal failure in small animals is creatininemia, hypertension and proteinuria. Diagnosing them in small animals with chronic renal failure is an important step to establish stages and substages of the disease according to International Renal Interest Society. In order to assign the appropriate treatment, monitoring it and predict the course of the disease, it was diagnosed the stages of CRF by determining the serum creatinine concentration. Along with this, there is an important determination of CRF substages depending on indices of proteinuria (clarifying its causes) and blood pressure that indicates the degree of target-organ damage. Hence, the main changes in the metabolism of the organism of small animals with chronic renal failure relate mainly metabolic processes of protein, and water-mineral metabolism. It has been determined that, during treatment, feeding cats and dogs on diet Royal Canin «Renal» (based on a low protein concentration, the required content of electrolytes, vitamins, and lipids) decreases the time of occurrence of sustained remission of animals in 4 times.

Key words: chronic renal failure, metabolism, diet, cats, dogs.

\section{Вступ}

За несвоєчасної діагностики захворювань сечової системи котів і собак та/або неадекватного лікування виникає хронічна ниркова недостатність (ХНН). ХНН розвивається в результаті поступової загибелі нефронів за будь-якого прогресуючого захворювання нирок (Bajnbridzh and Jelliot, 2003). Зазвичай етіологія ХНН у дрібних тварин невідома, а первинний чинник відсутній при тому, що пошкодження нирок зберігається i прогресує. Найбільш типовими причинами, що сприяють виникненню ХНН, є вік, генетична схильність, забруднення навколишнього середовища та захворювання незаразної та заразної етіології (O’Neill et al., 2013). Найбільш розповсюдженими причинами ХНН у котів і собак можуть бути первинний хронічний інтерстиціальний нефрит; незворотня гостра ниркова недостатність (ГНН); амілоїдоз; полікістоз нирок; гломерулонефрит; пієлонефрит; білатеральний нефролітіаз та ін. (Ynternet-resurs, 2014). Поряд з цим недоїдання i/aбо неправильне харчування є однією 3 основних причин захворюваності і смертності дрібних тварин із ХНН (3 і 4 стадіi). Звідси, метою даної роботи було вивчення впливу дієтичного харчування на перебіг метаболічних процесів у котів і собак із ХНH за їх лікування, власне спостереження за тривалістю часу виникнення стійкої ремісії у дрібних тварин.

\section{Матеріал і методи досліджень}

Дослідження проводили в умовах ветеринарної клініки «Zоолюкс».Тваринам, які підлягали дослідженню, було рекомендовано дієтичне харчування торгової марки RoyalCanin. Рекомендації засновані на анамнезі, клінічному огляді, спеціальному та лабораторному дослідженні кожного пацієнта, результати яких представлені у попередніх наших роботах (Lugova and Kalachnjuk 2015).

\section{Результати та їх обговорення}

Дослідженнями було доведено, що призначення дієтичного харчування, збільшило тривалість життя та знизило ускладнення, спричинені ХНН у дрібних тварин (Larsen et al., 2012; Lugova and Kalachnjuk $2015,2016)$, тобто вона посилює ефект лікування та дає можливість керувати перебігом ХНН. Дієтичне харчування полягає у:наявності зменшеної кількості білка задля контролю азотистого обміну та кислотнолужного балансу;мінеральному балансі $\left(\mathrm{Na}^{+}, \mathrm{K}^{-}, \mathrm{P}^{-}\right.$, $\mathrm{Ca}^{2+}, \mathrm{Mg}^{2+}$ ); обмеженні $\mathrm{Na}^{+}$задля контролю рівня кров'яного тиску;компенсації зменшеної кількості білка за рахунок концентрації жиру (для забезпечення енергіi).

Ветеринарна дієта RoyalCanin «Renal» поліпшує стан за ХНН у дрібних тварин, адже в своєму складі містить низький вміст фосфору, риб'ячий жир (Омега-3), комплекс антиоксидантів, комбінацію білків високої засвоюваності та пребіотиків (рис. 1.).

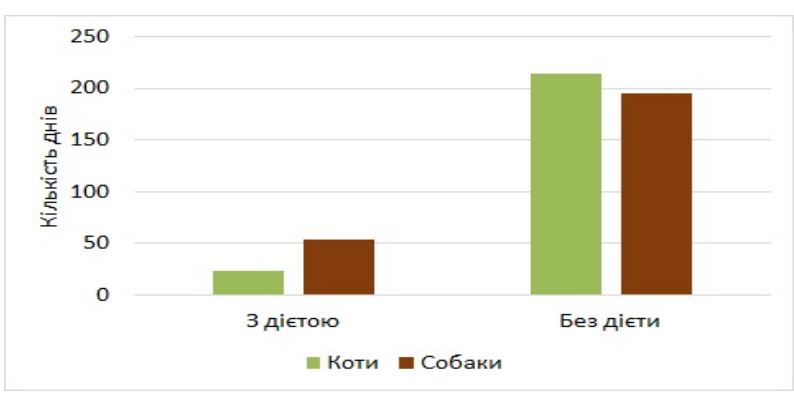

Рис. 1. Тривалість часу стабілізації стану здоров'я дрібних тварин із ХНН, утримуваних за дістою RoyalCanin «Renal» і без неї, де кількість днів - це час від визначення діагнозу до останнього контрольного прийому паціснта або визначення його стійкої ремісії 


\section{Висновки}

Дієтичне харчування є важливим етапом консервативної терапії за ХНН. Рекомендації щодо призначення дієти повинні бути засновані на низькій концентрації білка, необхідному вмісті електролітів, вітамінів та ліпідів. Отже, дієтотерапія впливає на тривалість часу стабілізації стану здоров'я дрібних тварин із $\mathrm{XHН,} \mathrm{скорочуючи} \mathrm{його} \mathrm{майже} \mathrm{в} 4$ рази. Вивчення впливу дієтичного харчування потребує детальнішого вивчення обмінних процесів в організмі дрібних тварин з метою контрою і корекції перебігу захворювання під час його лікування.

\section{Бібліографічні посилання}

Bajnbridzh, D., Jelliot D. (2003). Nefrologija i urologija sobak i koshek. Per. c angl. E. Mahijanova. M.: AKVARIUM LTD. 272. (in Russian).

Polzin D.J. (2007). 11 guidelines for conservatively treating chronic kidney disease. Veterinary Medicine. 102(12), 788-799.

O’Neill, D.G., Elliott, J., Church, D.B. [et al]. (2013). Chronic Kidney Diseasein Dogsin UK Veterinary Practices: Prevalence, Risk Factors, and Survival.
Journal of Veterinary Internal Medicine. 27(4), 814821.

Hronycheskaja pochechnaja nedostatochnost' Ynternetresurs.:

http://www.vetmedicus.ru/vetarticles/khronicheskayapochechnaya-nedostatochnost-hpn.php. (in Russian).

Lugova, Je.S., Kalachnjuk, L.G. (2015). Stadijnist' hronichnoi' nyrkovoi' nedostatnosti u dribnyh tvaryn. Nauk. visnyk LNUVMtaBT im. S.Z. G'zhyc'kogo. L'viv. 17, 1(61), 2, 89-91 (in Ukrainian).

Lugova, Je.S., Kalachnjuk, L.G. (2015). Hronichna nyrkova nedostatnist' dribnyh tvaryn i arterial'na gipertenzija. Nauk. visnyk LNUVMBT im. S.Z. G'zhyc'kogo. L'viv. 17, 2(62), 130-133 (in Ukrainian).

Luhova, Ye., Kalachnyuk, L. (2016). Proteinuria in the cats with chronic kidney disease and its correction// 2nd International Scientific Conference of the Veterinary Medicine Students, Faculty of Veterinary Medicine, Warsaw University of Life Science, Poland, May, 15th 2016: Abstract Book, Warsaw University of Life Science 47.

Larsen, J.A., Parks, E.M., Heinze, C.R., Fascetti A.J. (2012). Evaluation of recipes for home-prepared diets for dogs and cats with chronic kidney disease. J. Am. Vet. Med. Assoc. 240, 5, 532-538.

Стаття надійшла до редакиії 1.10.2016 